\title{
DNA repair genes $X R C C 1$ and $X R C C 3$ polymorphisms and their relationship with the level of micronuclei in breast cancer patients
}

\author{
Raquel A. Santos ${ }^{1}$, Ana Claudia Teixeira ${ }^{1}$, Monica B. Mayorano ${ }^{1}$, Helio H.A. Carrara ${ }^{2}$, \\ Jurandyr M. Andrade ${ }^{2}$ and Catarina S. Takahashi, ${ }^{1,3}$ \\ ${ }^{1}$ Departamento de Genética, Faculdade de Medicina de Ribeirão Preto, Universidade de São Paulo, \\ Ribeirão Preto, SP, Brazil. \\ ${ }^{2}$ Departamento de Ginecologia e Obstetrícia, Faculdade de Medicina de Ribeirão Preto, \\ Universidade de São Paulo, Ribeirão Preto, SP, Brazil. \\ ${ }^{3}$ Departamento de Biologia, Faculdade de Filosofia, Ciências e Letras de Ribeirão Preto, \\ Universidade de São Paulo, Ribeirão Preto, SP, Brazil.
}

\begin{abstract}
Breast cancer $(\mathrm{BC})$ is the most prevalent type worldwide, besides being one of the most common causes of death among women. It has been suggested that sporadic BC is most likely caused by low-penetrance genes, including those involved in DNA repair mechanisms. Furthermore, the accumulation of DNA damage may contribute to breast carcinogenesis. In the present study, the relationship between two DNA repair genes, viz., XRCC1 (Arg399G/n) and $X R C C 3$ (Thr241Met) polymorphisms, and the levels of chromosome damage detected in 65 untreated BC women and 85 healthy controls, was investigated. Chromosome damage was evaluated through micronucleus assaying, and genotypes determined by PCR-RFLP methodology. The results showed no alteration in the risk of BC and DNA damage brought about by either XRCC1 (Arg399G/n) or XRCC3 (Thr241Met) action in either of the two groups. Nevertheless, on evaluating $B C$ risk in women presenting levels of chromosome damage above the mean, the XRCC 3 Thr241Met polymorphism was found to be more frequent in the BC group than in the control, thereby leading to the conclusion that there is a slight association between XRCC3 $(241 \mathrm{C} / \mathrm{T})$ genotypes and BC risk in the subgroups with higher levels of chromosome damage.
\end{abstract}

Key words: DNA repair polymorphisms; breast cancer; micronucleus assay.

Received: March 10, 2010; Accepted: June 9, 2010.

Breast cancer (BC) is one of the most common causes of death among women, with every indication of a slow and steady decrease in the age of onset. The risk factors for $\mathrm{BC}$ include the early age of menarche, delayed menopause, the use of contraceptives, hormonal replacement therapy, the above average body-mass index, exposure to environmental pollutants, smoking and alcohol use (Kristensen and Borresen-Dale, 2000; Hulka and Moorman, 2001; Kang et al., 2002). However, it is generally believed that the initiation of $\mathrm{BC}$ is a consequence of cumulative genetic damage thereby leading to genetic alterations, with subsequent activation of proto-oncogenes and inactivation of tumor-suppressor genes (Mitrunen and Hirvonen, 2003). A large number of genetic variants associated with $\mathrm{BC}$ risk have been identified in genes involved in a wide variety of functions, including steroid hormone metabolism, detoxifica-

Send correspondence to Raquel Alves dos Santos. Faculdade de Medicina de Ribeirão Preto, Departamento de Genética, Bloco G, Av. Bandeirantes 3900, 14049-900 Ribeirão Preto, SP, Brazil. E-mail: rasantos@rge.fmrp.usp.br. tion of environmental carcinogens, tumor suppression and DNA damage repair (Dunning et al., 1999).

Polymorphisms in DNA repair genes are common. Studies have revealed that the effects of these polymorphisms on DNA repair ability contribute to individual differences (Pachkowski et al., 2006). There are two important genes involved in this process. One, the X-Ray Repair Cross Complementing 1 (XRCC1) gene involved in the Base Excision Repair (BER) pathway, is linked with a scaffolding protein that directly associates with other proteins, such as DNA polymerase $B$, PARP (ADP-ribose polymerase) and DNA ligase III, in a complex that facilitates processes of BER DNA repair (Caldecott et al., 2003). The other, $X R C C 3$, one of the key components of the homologous repair (HR) pathway, functions in the cross-link repair of DNA double-strand breaks (DSBs) by interacting and stabilizing Rad51 (Schild et al., 2000; Thompson and Schild, 2002).

It is common knowledge that chromosome damage results from non- or misrepaired DSBs, with many poly- 
morphisms, such as those of DNA repair genes, having been associated with increased cancer risk, and a possibly even higher level of chromosome damage (Norppa 2004).

Thus, the aim hereby was to investigate the relationship between XRCC1 (Arg399Gln) and XRCC3 (Thr241Met) SNPs and chromosomal damage in untreated $\mathrm{BC}$ women and healthy controls.

Blood samples for genotyping and micronucleus assaying were obtained from 65 untreated women, with ages ranging from 25 to 60 (mean age 50.6), diagnosed with in situ or invasive ductal breast carcinoma and free from any pathological manifestation associated with the use of medication and possibly leading to DNA damage. Of the 65 women in the patient group $33(50.7 \%)$ were post- and 32 (49.3\%) pre-menopausal. The control group consisted of 85 women, ages ranging from 25 to 60 (mean age 48.7) with $42(49.4 \%)$ post- and $43(50.6 \%)$ premenopausal. Each was enrolled in the study after detailed investigation, thereby ensuring the absence from any form of breast pathology. These were matched to patients according to the following variables: all the volunteers came from the same geographical location, with identical dietary habits, and without prior occupational exposure to genotoxic chemicals. None reported alcohol consumption, genotoxic medicine intake, the presence of known inherited genetic disorders or chronic diseases, or the exposure to ionizing or non-ionizing radiation, even for diagnostic or therapeutic purposes, for at least one month previously. The investigation received prior approval by the National Ethics Committee (CONEP: 1217/2004), and was undertaken in accordance with defined ethical standards. Informed consent was obtained from patients and controls before inclusion in the study and sample collection.

Genomic DNA samples were obtained from blood lymphocytes for genotyping by using a Wizard $\AA$ Genomic DNA Purification Kit (Promega, Madison, WI). G399A polymorphism of the XRCCl gene was determined by PCR-RFLP with the following primers: sense, 5'-TCTCCCTTGGTCTCCAACCT-3' and antisense, 5'-AGTAGTCTGCTGGCTCTGG-3'. The 402 bp product was digested overnight with $5 \mathrm{U}$ of the restriction enzyme MspI. The $\mathrm{G}$ allele was digested into 269 and $133 \mathrm{bp}$ fragments. Nevertheless, when the A allele was present, the $402 \mathrm{bp}$ fragment remained intact. C241T polymorphism of the $X R C C 3$ gene was genotyped with the following primers: sense, 5'-GGTCGAGTGACAGTCCAAAC-3' and antisense, 5'-TGCAACGGCTGAGGGTCTT-3'. The 455 bp product was digested overnight with $5 \mathrm{U}$ of the restriction enzyme NlaIII. The Leu allele was digested into 210, 140 and $105 \mathrm{bp}$ fragments.

In order to stimulate cell proliferation, lymphocyte cultures were prepared for micronucleus assaying by combining $0.5 \mathrm{~mL}$ of isolated lymphocytes in plasma with $5 \mathrm{~mL}$ of a complete medium containing $78 \%$ of RPMI (Sigma-Aldrich Co., USA), 20\% inactivated fetal bovine serum
(Gibco-Invitrogen, Denmark), and both of the antibiotics penicillin ( $5 \mu \mathrm{g} / \mathrm{mL}$, Sigma-Aldrich Co., USA) and streptomycin (10 $\mu \mathrm{g} / \mathrm{mL}$, Sigma-Aldrich Co., USA), as well as $2 \%$ phytohemagglutinin (Life Technologies, Grand Island, NY, USA). Cultures were incubated at $37^{\circ} \mathrm{C}$. According to the Fenech and Morley (1985) method, after $44 \mathrm{~h}$ of incubation, cytochalasin B (Sigma-Aldrich Co., USA) was added to the cultures to a final concentration of $4 \mu \mathrm{g} / \mathrm{mL}$. The cultures were stopped after $72 \mathrm{~h}$, whereat the cells were harvested by centrifugation, submitted to cold hypotonic treatment ( $1 \%$ of sodium citrate), and fixed in two changes of methanol-acetic acid (3:1). The fixed cells were spread onto pre-cleaned glass slides, air-dried, and then stained with a Giemsa solution (Sörensen Buffer, pH 6.8) for 7 min. 1000 binucleated cells were analyzed, whereupon micronucleus frequency (MNF), micronucleated cell frequency (MCF) and the nuclear division index (NDI) were determined for each cell according to criteria described by Fenech (2000).

The Mann-Whitney statistical test was applied for comparing MNF between patients and controls. The level of DNA damage in different genotypes was analyzed with one-way ANOVA, whereas statistical differences between groups for BC risk was calculated using Fisher's exact test (two-tailed). On considering that high chromosome damage could possibly be associated with inefficient DNA repair, subjects with $\mathrm{MN}$ frequencies higher than the mean for the respective group, were selected for further analysis, as recommended by Synowiec et al. (2008). Crude odds ratios (ORs) were calculated and obtained with 95\% confidence intervals (CIs). Results were considered significant when $\mathrm{p}<0.05$.

The polymorphic variants of the two DNA repair genes, XRCC1 (399G/A) and XRCC3 (241 C/T), and genotype distribution of the $\mathrm{BC}$ and control groups, were in agreement with those predicted by Hardy-Weinberg equilibrium. There was no difference between patients and controls, as regards $X R C C 1$ and $X R C C 3$ genotype frequencies (Table 1). Although it has been suggested that $X R C C 1$ and $X R C C 3$ polymorphisms are involved in $\mathrm{BC}$ risk, we did not find such correlation, mainly due to the small sample size. Nevertheless, it has been revealed that subtle defects in DNA repair capacity, arising from low-penetrance genes or their combinations, are modified by other genetically determined or environmental risk factors and are correlated with $\mathrm{BC}$ risk (Synowiec et al., 2008).

We are aware that this is not an epidemiological study. Rather, our primary objective was to evaluate the correlation between genotype (variants of DNA repair genes) and phenotype (spontaneous chromosome damage). The results obtained after genotype analysis and chromosome damage expressed by MNF are presented in Table 1. In both patient and control groups, no genetic variant of $X R C C 1$ or $X R C C 3$ influenced the frequency of micronuclei detected in peripheral lymphocytes. We have previously re- 
Table 1 - The genotype frequencies of $X R C C 1$ and $X R C C 3$ gene variants, and levels of chromosome damage as evaluated by micronucleus (MN) assay in untreated breast cancer patients and controls.

\begin{tabular}{|c|c|c|c|c|c|c|c|}
\hline \multirow[t]{2}{*}{ Genotype } & \multicolumn{2}{|c|}{$\begin{array}{l}\text { Breast cancer patients } \\
\qquad(\mathrm{n}=65)\end{array}$} & \multicolumn{2}{|c|}{$\begin{array}{l}\text { Controls } \\
(\mathrm{n}=85)\end{array}$} & \multirow[t]{2}{*}{$\begin{array}{c}\text { OR } \\
(95 \% \mathrm{CI})\end{array}$} & \multirow[t]{2}{*}{$\begin{array}{c}\text { Breast cancer patients } \\
\text { MNF (\%o) M } \pm \text { SD }\end{array}$} & \multirow[t]{2}{*}{$\begin{array}{c}\text { Controls MNF (\%) } \\
\mathrm{M} \pm \mathrm{SD}\end{array}$} \\
\hline & $\mathrm{N}$ & Frequency & $\mathrm{N}$ & Frequency & & & \\
\hline \multicolumn{8}{|l|}{$X R C C 1$} \\
\hline Arg/Arg & 24 & 0.37 & 24 & 0.28 & 1.0 (reference) & $16.9 \pm 10$ & $10.1 \pm 5.8$ \\
\hline $\mathrm{Arg} / \mathrm{Gln}$ & 39 & 0.60 & 53 & 0.62 & $0.73(0.3-1.4)$ & $20.1 \pm 11.1$ & $8.9 \pm 6.5$ \\
\hline $\mathrm{Gln} / \mathrm{Gln}$ & 2 & 0.03 & 8 & 0.10 & $0.25(0.04-1.3)$ & $33 \pm 5.6$ & $10.8 \pm 5.3$ \\
\hline \multirow[t]{2}{*}{$\mathrm{Arg} / \mathrm{G} \ln +\mathrm{Gln} / \mathrm{Gln}$} & 41 & 0.63 & 61 & 0.72 & $0.6(0.3-1.3)$ & $20.7 \pm 10.8$ & $9.3 \pm 6.2$ \\
\hline & & & & & & $\mathrm{p}=0.2$ & $\mathrm{p}=0.7$ \\
\hline \multicolumn{8}{|l|}{$X R C C 3$} \\
\hline Thr/Thr & 28 & 0.43 & 49 & 0.58 & 1.0 (reference) & $18.7 \pm 8.9$ & $11.2 \pm 6.3$ \\
\hline Thr/Met & 31 & 0.48 & 29 & 0.34 & $1.8(0.9-3.7)$ & $19.7 \pm 12.2$ & $8.3 \pm 5.3$ \\
\hline Met/Met & 6 & 0.09 & 7 & 0.08 & $1.5(0.4-4.9)$ & $20.3 \pm 12.2$ & $10.8 \pm 7.8$ \\
\hline \multirow[t]{2}{*}{ Thr/Met+Met/Met } & 37 & 0.57 & 36 & 0.42 & $1.7(0.9-3.4)$ & $19.8 \pm 12.1$ & $9.3 \pm 6$ \\
\hline & & & & & & $\mathrm{p}=0.9$ & $\mathrm{p}=0.3$ \\
\hline
\end{tabular}

MNF: micronucleus frequency; OR: odds ratio; M: mean; SD: standard deviation.

ported that untreated Brazilian BC patients displayed higher levels of chromosome damage than healthy controls (Santos et al., 2010). Furthermore, it has been suggested that genome damage in lymphocytes may be correlated with cancer-initiating events in target tissues, via a common genetic, dietary or environmental factor (Bonassi et al., 2007). Hence, genetic polymorphisms might explain part of the association between chromosome damage levels and cancer risk (Norppa, 2004). However, in a pooled analysis, Mateuca et al. (2008) suggested that single DNA repair gene polymorphisms are not likely to have a major impact on MN frequencies, whereas combinations of different DNA repair genes, and the interplay between $h O G G 1^{326}, X R C C 1^{399}, X R C C 3^{241}$, genotypes and environmental factors are more likely to modulate $\mathrm{MN}$ levels.

Table 2 shows the distribution of XRCC1 (399G/A) and XRCC3 $(241 \mathrm{C} / \mathrm{T})$ genotypes in groups of patients and controls with higher than mean level of spontaneous DNA damage in both (19.3 for patients and 10.4 for controls). On considering $X R C C 1$ gene variants, no correlation between the frequencies of genotypes and $\mathrm{MN}$ was found. On the other hand, XRCC3 polymorphism was only slightly associated with $\mathrm{BC}$ risk in those individuals that presented higher levels of chromosome damage. This was interesting, especially when considering that susceptibility and risk biomarkers contribute to identifying high-risk subgroups of the population, independent of their association with exposure or involvement in a defined pathway or mechanism (Boffeta, 2009). Notwithstanding, such a correlation cannot be emphasized, especially on considering that when lymphocytes of $\mathrm{BC}$ patients and healthy controls were challenged to repair the in vitro etoposide-induced DNA damage, the response was similar in both groups, as previously demonstrated (Teixeira et al., 2009). Moreover, the manifestation of the effects of DNA repair enzyme polymorphisms may be quite different between breast tissue undergoing continual exposure to the effects of hormones and lymphocytes.

Table 2 - DNA repair-gene polymorphisms in breast cancer patients and controls with high levels of chromosome damage.

\begin{tabular}{|c|c|c|c|c|c|}
\hline \multirow[t]{2}{*}{ Genotype } & \multicolumn{2}{|c|}{ Breast cancer patients $(\mathrm{n}=32)$} & \multicolumn{2}{|c|}{ Controls $(\mathrm{n}=21)$} & \multirow[t]{2}{*}{ OR $(95 \% \mathrm{CI})$} \\
\hline & Number & Frequency & Number & Frequency & \\
\hline \multicolumn{6}{|l|}{$X R C C 1$} \\
\hline Arg/Arg & 9 & 0.28 & 4 & 0.19 & 1.0 (reference) \\
\hline $\mathrm{Arg} / \mathrm{G} \ln +\mathrm{G} \ln / \mathrm{Gln}$ & 23 & 0.72 & 17 & 0.81 & $1.6(0.4-6.3)$ \\
\hline \multicolumn{6}{|l|}{$X R C C 3$} \\
\hline Thr/Thr & 12 & 0.37 & 15 & 0.71 & 1.0 (reference) \\
\hline Thr/Met+Met/Met & 20 & 0.63 & 6 & 0.29 & $4.1(1.2-13.6) \uparrow$ \\
\hline
\end{tabular}

OR: odds ratio. 
In conclusion, the levels of chromosome damage observed in breast cancer patients and healthy controls were not associated to the XRCC1 (399G/A) and XRCC3 (241 $\mathrm{C} / \mathrm{T}$ ) genotypes. Nevertheless there actually was a weak association between several other XRCC3 genotypes and BC risk in the subgroup where this damage was higher. Such an association must be interpreted with caution, when considering that the odds ratios obtained, even though pertaining to low-penetrance genes, were statistically significant. Thus, only the common expression of a considerable number of such genes could possibly change this statistical significance into a biological or medical one.

\section{Acknowledgments}

The authors gratefully acknowledge the cooperation of all the volunteers who participated in this study. This investigation was supported in part by the Conselho Nacional de Desenvolvimento Científico e Tecnológico - CNPq (grants 400887/2005 and 3473493/2004-7), as well as by Coordenação de Aperfeiçoamento de Pessoal de Nível Superior - CAPES fellowships to RA Santos and MB Mayorano and Fundação de Amparo a Pesquisa do Estado de São Paulo - FAPESP fellowship to Ana Claudia Teixeira.

\section{References}

Boffeta P (2009) Biomarkers in cancer epidemiology: An integrative approach. Carcinogenesis 131:121-126.

Bonassi S, Znaor A, Ceppi M, Lando C, Chang WP, Holland N, Kirsch-Volders M, Zeiger E, Ban S, Barale R, et al. (2007) An increased micronucleus frequency in peripheral blood lymphocytes predicts the risk of cancer in humans. Carcinogenesis 28:625-631.

Caldecott KW (2003) XRCC1 and DNA strand break repair. DNA Repair 18:955-69.

Dunning AM, Healey CS, Pharoah PD, Teare MD, Ponder BA and Easton DF (1999) A systematic review of genetic polymorphisms and breast cancer risk. Cancer Epidemiol Biomarkers Prev 8:843-854.

Fenech M and Morley A (1985) Measurement of micronuclei in lymphocytes. Mutat Res 147:29-36.

Fenech M (2000) The in vitro micronucleus technique. Mutat Res 455:81-95.

Hulka BS and Moorman PG (2001) Breast cancer: Hormones and other risk factors. Maturitas 38:103-116.
Kang HJ, Kim SW, Kim HJ, Ahn SJ, Bae JY, Park SK, Kang D, Hirvonen A, Choe KJm and Noh DY (2002) Polymorphisms in the estrogen receptor-alpha gene and breast cancer risk. Cancer Lett 178:175-180.

Kristensen NS and Borresen-Dale AL (2000) Molecular epidemiology of breast cancer: Genetic variation in steroid hormone metabolism. Mutat Res 462:323-333.

Mateuca RA, Roelants M, Iarmarcovai G, Peter VA, Godderis L, Tremp A, Bonassi S, Fenech M, Lefranc JLB and KirschVolders M (2008) hOGG1326, XRCC1399 and XRCC3241 polymorphisms influence micronucleus frequencies in human lymphocytes in vivo. Mutagenesis 23:35-41.

Mitrunen K and Hirvonen A (2003) Molecular epidemiology of sporadic breast cancer. The role of polymorphic genes involved in oestrogen biosynthesis and metabolism. Mutat Res 544:9-41.

Norppa H (2004) Cytogenetic biomarkers and genetic polymorphisms. Toxicol Lett 149:309-34.

Pachkowski BF, Winkel S, Kubota Y, Swenberg JA, Millikan RC and Nakamura J (2006) XRCC1 genotype and breast cancer: Functional studies and epidemiologic data show interactions between XRCC1 codon 280 His and smoking. Cancer Res 66:2860-8.

Santos RA, Teixeira AC, Mayorano MB, Carrara HH, Andrade JM and Takahashi CS (2010) Basal levels of DNA damage detected by micronuclei and comet assays in untreated breast cancer patients and healthy women. Clin Exp Med 10:87-92.

Schild D, Lio YC, Collins DW, Tsomondo T and Chen DJJ (2000) Evidence for simultaneous protein interactions between human Rad51 paralogs. Biol Chem 275:16443-16449.

Synowiec E, Stefanska J, Morawiec Z, Blasiak J and Wozniak K (2008) Association between DNA damage, DNA repair genes variability and clinical characteristics in breast cancer patients. Mutat Res 648:65-72.

Teixeira AC, Dos Santos RA, Poersch A, Carrara HH, de Andrade JM and Takahashi CS (2009) DNA repair in Etoposide-induced DNA damage in lymphocytes of breast cancer patients and healthy women. Int J Clin Exp Med 20:280-288.

Thompson LH and Schild D (2002) Recombinational DNA repair and human disease. Mutat Res 509:49-78.

Associate Editor: Carlos F.M. Menck

License information: This is an open-access article distributed under the terms of the Creative Commons Attribution License, which permits unrestricted use, distribution, and reproduction in any medium, provided the original work is properly cited. 